Evidence-Based Speech-Language Pathology and Audiology

\section{Fonoaudiologia Baseada} em Evidências

Luciana da Silva Barberena ${ }^{1}$ Brunah de Castro Brasil ${ }^{1,2}$ Roberta Michelon Melo ${ }^{1}$ Carolina Lisbôa Mezzomo ${ }^{1,3}$ Helena Bolli Mota ${ }^{1,3}$ Márcia Keske-Soares ${ }^{1,3}$

Keywords

Ultrasonics Speech

Phonetics

Speech, Language and Hearing Sciences

Voice

Swallow

Myofunctional Therapy

\section{Descritores}

Ultrassom

Fala

Fonética

Fonoaudiologia Voz

Deglutição

Terapia Miofuncional

Correspondence address:

Roberta Michelon Melo

Rua Marechal Floriano Peixoto, 1.751,

Centro, Santa Maria (RS), Brasil,

CEP: 97015-372.

E-mail: roberta_m_melo@hotmail.com

Received: $12 / 23 / 2013$

Accepted: 09/01/2014

\section{Ultrasound applicability in Speech Language Pathology and Audiology}

\section{Aplicabilidade da ultrassonografia na Fonoaudiologia}

\begin{abstract}
Purpose: To present recent studies that used the ultrasound in the fields of Speech Language Pathology and Audiology, which evidence possibilities of the applicability of this technique in different subareas. Research strategy: A bibliographic research was carried out in the PubMed database, using the keywords "ultrasonic," "speech," "phonetics," "Speech, Language and Hearing Sciences," "voice," "deglutition," and "myofunctional therapy," comprising some areas of Speech Language Pathology and Audiology Sciences. The keywords "ultrasound," "ultrasonography," "swallow," "orofacial myofunctional therapy," and "orofacial myology" were also used in the search. Selection criteria: Studies in humans from the past 5 years were selected. In the preselection, duplicated studies, articles not fully available, and those that did not present direct relation between ultrasound and Speech Language Pathology and Audiology Sciences were discarded. Data analysis: The data were analyzed descriptively and classified subareas of Speech Language Pathology and Audiology Sciences. The following items were considered: purposes, participants, procedures, and results. Results: We selected 12 articles for ultrasound versus speech/phonetics subarea, 5 for ultrasound versus voice, 1 for ultrasound versus muscles of mastication, and 10 for ultrasound versus swallow. Studies relating "ultrasound" and "Speech Language Pathology and Audiology Sciences" in the past 5 years were not found. Conclusion: Different studies on the use of ultrasound in Speech Language Pathology and Audiology Sciences were found. Each of them, according to its purpose, confirms new possibilities of the use of this instrument in the several subareas, aiming at a more accurate diagnosis and new evaluative and therapeutic possibilities.
\end{abstract}

\section{RESUMO}

Objetivo: Apresentar estudos recentes que utilizaram a ultrassonografia na área da Fonoaudiologia, os quais evidenciam possibilidades de aplicabilidade dessa técnica nas diferentes subáreas. Estratégia de pesquisa: Foi realizada uma pesquisa bibliográfica na base de dados PubMed, utilizando como descritores "ultrasonic"; "speech"; "phonetics"; "Speech, Language and Hearing Sciences"; "voice"; "deglutition" e "myofunctional therapy", contemplando algumas das áreas da Fonoaudiologia. Foram também empregados na busca os termos "ultrasound"; "ultrasonography"; "swallow"; "orofacial myofunctional therapy" e "orofacial myology". Critérios de seleção: Como critérios da pesquisa em base de dados, selecionaram-se: estudos dos últimos cinco anos e estudos em humanos. Na pré-seleção, foram descartados estudos duplicados, não disponibilizados na íntegra e que não apresentassem relação direta da ultrassonografia com a Fonoaudiologia. Análise dos dados: A análise dos dados foi realizada de forma descritiva e separada para cada subárea da Fonoaudiologia. Consideraram-se os itens: objetivos; sujeitos; procedimentos e resultados. Resultados: Foram selecionados 12 artigos para a subárea ultrassom versus fala/fonética; cinco para ultrassom versus voz; um para ultrassom versus músculos mastigatórios e dez para ultrassom versus deglutição. Não foram encontrados estudos referentes aos últimos cinco anos relacionando "ultrassom" e "Fonoaudiologia". Conclusão: Foram encontradas diferentes pesquisas que se voltaram ao emprego da ultrassonografia na Fonoaudiologia. Cada qual, a partir de seu objetivo, confirma novas possibilidades de uso desse instrumento nas diversas subáreas, visando a um diagnóstico mais preciso e novas possibilidades, tanto avaliativas quanto terapêuticas.

Study carried out at the Graduate Program in Human Communication Disorders, Universidade Federal de Santa Maria - UFSM - Santa Maria (RS), Brazil.

(1) Graduate Program in Human Communication Disorders, Universidade Federal de Santa Maria - UFSM - Santa Maria (RS), Brazil.

(2) Universidade Federal do Rio Grande do Sul - UFRGS - Porto Alegre (RS), Brazil.

(3) Speech Language Pathology and Audiology Course, Universidade Federal de Santa Maria - UFSM - Santa Maria (RS), Brazil.

Financial support: Fundação de Amparo à Pesquisa do Estado do Rio Grande do Sul - FAPERGS e Coordenação de Aperfeiçoamento de Pessoal de Nível Superior - CAPES

Conflict of interests: nothing to declare. 


\section{INTRODUCTION}

The Speech Language Pathology and Audiology clinic uses various instruments to validate its actions. It is common to use assessment protocols, often subjective, to define the different steps and procedures of Speech Language Pathology and Audiology therapy. In recent years, there is a growing search for instruments and more direct and quantifying analysis, seeking greater accuracy of the data collected, as well as of the diagnostics and prognostics.

The auditory-perceptual analysis is used widely in the areas of speech and language and can be complemented by other instrumental evaluations, so that the participant is evaluated and treated in all respects of its communicative disorder. Acoustic analysis of speech and voice has been used for a long time as tool for analysis of altered cases, for promoting more accurate diagnoses, and as the monitoring procedure of the therapeutic process, both by speech language pathologist and by the patient ${ }^{(1-4)}$. The articulatory analysis in the area of speech and orofacial motricity emerges as a new possibility, especially at the national level ${ }^{(5-10)}$, for integration of these analyses already mentioned, using, for example, the ultrasonography for evaluation of tongue movements ${ }^{(11-22)}$, and of the hyoid bone ${ }^{(19,23-27)}$, without inserting devices within the oral cavity.

The investigation of tongue movements is one of the possibilities of using this type of articulation assessment, which is not considered invasive and is available with minimum interference in the visualization of intraoral movements ${ }^{(28,29)}$, enabling research in various subareas of Speech Language Pathology and Audiology. The knowledge of speech language pathologists about the possibilities of use of ultrasound in a variety of Speech Language Pathology and Audiology alterations (the focus of this article) can affect important research in the area and consequent relevant findings. The use of ultrasound allows the speech language pathologist to perform articulatory data analysis of the participant assessed and of the patient undergoing therapeutic procedure ${ }^{(11,12,30)}$.

\section{PURPOSE}

To present studies of the past 5 years that used ultrasonography in the field of Speech Language Pathology and Audiology, which can show possibilities of applicability of this technique in different subareas of Speech Language Pathology and Audiology.

\section{RESEARCH STRATEGY}

A narrative review of the literature based on the question that guided this study was conducted: "In what areas and in what way the ultrasound data can contribute to the knowledge of Speech Language Pathology and Audiology?"

To answer this question, a literature review was conducted from May to July of 2013. It was performed initially in the PubMed international database, which is maintained by the National Center for Biotechnology Information (NCBI) at the National Institute of Health (NIH). This search strategy was chosen because the tool catalogs scientific articles published in journals indexed in major global scientific collections.
The keywords provided by Health Sciences Descriptors (DeCS) used in the research were "ultrasonic," "speech," "phonetics," "Speech, Language and Hearing Sciences," "voice," "deglutition," and "myofunctional therapy," covering some of the areas of the Speech Language Pathology and Audiology. The terms "ultrasound," "ultrasonography," "swallow," "orofacial myofunctional therapy," and "orofacial myology" were also researched in the examination, even though they are not descriptors provided by the Regional Library of Medicine (BIREME), because they are found several times in articles related to the area. The combinations of the descriptors and terms were as follows: ultrasonic AND speech, ultrasound AND speech, ultrasonography AND speech, and thus successively with the other terms and descriptors.

After the search for articles with the descriptors and terms quoted, the abstracts of the studies were searched and, if they were of interest to this study, the full text of the respective articles were searched.

In this way, to get some full articles not available in PubMed, the Coordenação de Aperfeiçoamento de Pessoal de Nivel Superior (CAPES) journals portal was also used, through the search for the topic with the job title.

The databases cited were prioritized due to the their easy access, and it was done by specific agreements made by the Universidade Federal de Santa Maria, of which the authors of this article are part of.

\section{SELECTION CRITERIA}

The following were selected as search criteria in the database: studies of the past 5 years, and studies in humans. In this way, 320 abstracts were found in the survey conducted through the PubMed database. Figure 1 shows the total number of articles for each area of the Speech Language Pathology and Audiology before the adoption of the criteria for inclusion and exclusion of articles that comprised the present literature review.

As stated in the Research Strategy section, after the search in the database, there was a preselection of the material collected from the abstracts. The inclusion criteria of the work in this review were: to use ultrasound as a tool for obtaining data; to relate the ultrasound information to some of the areas of interest of the Speech Language Pathology and Audiology — speech, phonetics, voice, orofacial motricity, and swallowing; to find the availability of the full text, either in PubMed or in the CAPES journals portal.

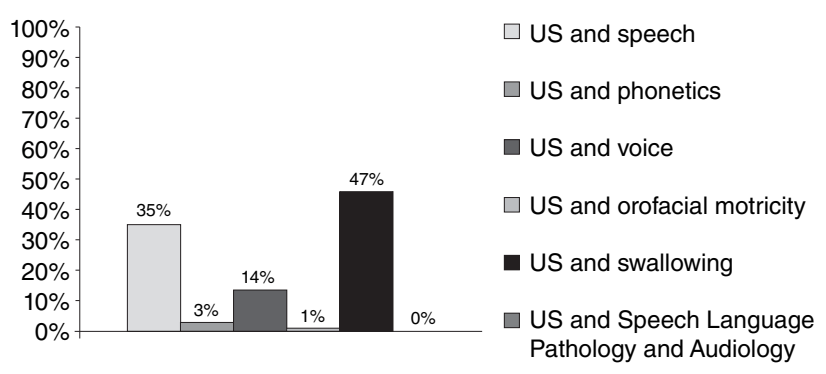

Caption: US = Ultrasound

Figure 1. Total of selected abstracts in the PubMed database as the intersection of the descriptors 
In the preselection, duplicate studies; articles not available in its entirety; and the ones that presented no direct relation of ultrasound with the Speech Language Pathology and Audiology, for example, articles that used ultrasound to investigate biopsies, carcinomas, and esophageal swallowing, were discarded. At the end of the survey, 12 articles for the subarea ultrasound versus speech/phonetics, 5 for ultrasound versus voice; 1 for ultrasound versus masticatory muscles, and 10 for ultrasound versus swallowing were selected. Although they are descriptors used in this review, no studies were found when crossing the terms "ultrasound" and "Speech Language Pathology and Audiology" (Speech, Language and Hearing Sciences). Therefore, we selected 28 articles, being the oldest of 2008 and the latest of 2013, for this review.

\section{DATA ANALYSIS}

The data were analyzed in a descriptive manner and separately for each subarea of Speech Language Pathology and Audiology, as described earlier.

The items analyzed were the following:

- purposes,

- subjects considered in the study,

- important procedures, and

- the main results of the study.

\section{RESULTS}

\section{Ultrasound and speech/phonetics}

The studies related to the research "Ultrasound and Speech" aimed, in general,

- to apply the ultrasound images for speech therapy ${ }^{(11,12,30)}$;

- to investigate the coarticulatory effects, for example, of the syllable CV (consonant-vowel) versus CVC (consonantvowel-consonant), or vowel context ${ }^{(13,18,31)}$;

- to describe some descriptors of the tongue movements, among them, the speed and the distance covered ${ }^{(14,16)}$;

- characterize the gestures involved in the production of consonant segments, as for instance the phoneme $/ \mathrm{r}^{\left({ }^{(15)} \text {; }\right.}$

- to describe compensatory articulatory strategies and hidden movements ${ }^{(32)}$; and

- to propose articulatory measures via ultrasonography ${ }^{(22)}$.

The definition of the sample was restricted to the purposes of the searches. Therefore, the articles that applied ultrasound data for the investigation of speech focused on participants with typi$\mathrm{cal}^{(13,15,16,18,31)}$ and atypical ${ }^{(11,12,14,16,30,32)}$ speech. Speech alterations were due to speech disorder ${ }^{(11,12)}$, glossectomy ${ }^{(14,16)}$, hearing $\operatorname{loss}^{(30)}$, and cleft palate ${ }^{(32)}$. The search for this subarea had on average 8.5 participants; of these, $64.9 \%$ were adults and $35.1 \%$ children.

As the characterization of the group of subjects, the observed methodological aspects are quite heterogeneous, also restricted to the research proposal (Chart 1).

The main results of the articles are also presented in Chart 1. The various possibilities of application of tongue ultrasound images in the speech subarea can be observed, because the identification of gestural patterns in an evaluative procedure to the insertion of this technology as a therapeutic procedure is available to the Speech Language Pathology and Audiology Clinic.

With the crossing of the descriptors related to "ultrasound" and "phonetic," a study ${ }^{(21)}$ directed to the research of speech segments was found. The article aims to analyze the images of the forms of the tongue of an individual, native speaker of a dialect of Nepal, during the production of plosives and affricates, voiced and voiceless, dental, retroflexes, and palatals. In this study, the authors believe that the spatial and dynamic information obtained via ultrasound image of the tongue can supplement the data obtained with the static electropalatography, related to the location and type of constriction of the tongue on the palate.

The results showed differences in the forms of the tongue, even if some were discreet, between location of the constriction of the devoiced and voiced consonant, of the consonant at the beginning and at the end of a syllable, and between different articulation points of the dialect investigated ${ }^{(21)}$.

The association between ultrasound and phonetic (Chart 2), although still small, as this bibliographic research shows, already allowed us to verify that the ultrasound images are able to provide specifics of a given language, based on the analysis of the dynamics of the sounds in real time. Such manipulation can also stimulate research in phonetics on the organization of syllabic sequences, coarticulation, and structural organizations of sounds.

\section{Ultrasound and voice}

The studies found and highlighted in Chart 3 showed welldifferentiated goals, investigating from the tone and length of muscles, measurement of mucosal wave, adaptation of speech valves, to literature review. Many studies have sought to compare and discuss the advantages, disadvantages, and the applicability of instruments such as ultrasound to electroglottography, video fluoroscopy, and computerized tomography ${ }^{(33-36)}$. Many of these techniques are widely used in the medical field and by speech language pathologists, but the ultrasound, for example, is a method that requires study and has been recruited on a larger scale for research in the field of Speech Language Pathology and Audiology.

The studies had an average of 49 participants ${ }^{(34-36)}$; the results showed improvements to the field and helped to spread the use of new techniques, improve them, and validate them.

The five studies reported the importance of using the method of ultrasound combined with other techniques, what could decrease the risk of postoperative complications ${ }^{(36)}$, determine laryngeal segments with better accuracy ${ }^{(35)}$, determine variations in muscle length ${ }^{(34)}$, as well as contribute to diagnosis and to an effective treatment plan $^{(33,37)}$.

\section{Ultrasound and masticatory muscles}

The only study found ${ }^{(8)}$ (Chart 4) relating the ultrasound technique and masticatory muscles (even though descriptors related, in general terms, to the orofacial motricity were used) presents an interdisciplinary work and the proposal of an integrated treatment for common disorders in Speech Language Pathology and Audiology Clinical Therapy - muscle changes resulting from occlusal disorders. 
Chart 1. Studies that have addressed the application of ultrasound in speech

\begin{tabular}{|c|c|c|c|c|}
\hline Author(s) & Objective(s) & Participant(s) & Important procedures & Results \\
\hline $\begin{array}{l}\text { Bernhardt } \\
\text { et al., } \\
2008^{(11)}\end{array}$ & $\begin{array}{l}\text { To investigate the } \\
\text { effects of short-term } \\
\text { therapy using US as } \\
\text { a visual feedback of } \\
\text { speech production of } \\
\text { children with speech } \\
\text { disorder in rural } \\
\text { communities in British } \\
\text { Columbia, Canada. }\end{array}$ & $\begin{array}{l}13 \text { students, } 8 \\
\text { boys and } 5 \text { girls, } \\
7-15 \text { years old, } \\
\text { participated } \\
\text { in therapy for } \\
\text { correction of } \\
\text { speech disorders, } \\
\text { but with still } \\
\text { persistent } \\
\text { disorders. }\end{array}$ & $\begin{array}{l}\text { The approach with ultrasonography } \\
\text { involved three phases: 1) six or seven } \\
\text { sessions without the use of US; 2) one } \\
\text { to three sessions with the US; 3) seven } \\
\text { to eight sessions without US. The target } \\
\text { sound focused was: / I /. }\end{array}$ & $\begin{array}{l}11 \text { individuals presented a rapid increase } \\
\text { in production of the target sound after the } \\
\text { second stage of treatment. According to the } \\
\text { therapists, the US contributed to significant } \\
\text { advances in a shorter period, as well as an } \\
\text { increase in the motivation of the participants. }\end{array}$ \\
\hline $\begin{array}{l}\text { Modha } \\
\text { et al., } \\
2008^{(12)}\end{array}$ & $\begin{array}{l}\text { To compare the } \\
\text { treatment segment } \\
/ \mathrm{r} / \text { with or without US } \\
\text { as a continuation of } \\
\text { previous studies. }\end{array}$ & $\begin{array}{l}\text { A 13-year-old } \\
\text { Canadian English } \\
\text { speaker boy } \\
\text { participant. He } \\
\text { received speech } \\
\text { therapy, however, } \\
\text { had not yet } \\
\text { acquired the } \\
\text { phoneme / I /. }\end{array}$ & $\begin{array}{l}\text { Nine meetings of } 30-45 \text { minutes were } \\
\text { held. The treatment initiated by a session } \\
\text { without US followed by two blocks of four } \\
\text { sections including treatment with the US } \\
\text { and two without. The therapeutic practice } \\
\text { included the imitative and spontaneous } \\
\text { production of the target sound in an } \\
\text { isolated form, syllables, words, and } \\
\text { sentences. The final evaluation was } \\
\text { performed after } 6 \text { weeks without speech } \\
\text { intervention. The perceptual analysis and } \\
\text { the acoustic analysis were performed, } \\
\text { and the point of maximum constriction of } \\
\text { the consonant was recorded. }\end{array}$ & $\begin{array}{l}\text { The values of the formants and the analysis } \\
\text { of trained listeners showed an improvement } \\
\text { in the production of } / r \text { /, particularly after the } \\
\text { introduction of US. }\end{array}$ \\
\hline $\begin{array}{l}\text { Pouplier, } \\
2008^{(13)}\end{array}$ & $\begin{array}{l}\text { To investigate the bias } \\
\text { of gestural intrusion } \\
\text { into segments, as } \\
\text { well as the effect of } \\
\text { consonants in coda } \\
\text { on initial segments. }\end{array}$ & $\begin{array}{l}\text { Eight native } \\
\text { speakers of } \\
\text { American } \\
\text { English, six men } \\
\text { and two women, } \\
\text { aged between } 22 \\
\text { and } 43 \text { years. }\end{array}$ & $\begin{array}{l}\text { The following words were collected in } \\
\text { coda: "top cop, sop, shop"; in Non-coda: } \\
\text { "kaa, taa, saw, shaw." With variation in } \\
\text { accent and position in the sentence. } \\
\text { Also, "taa kaa taa," "kaa taa kaa," "saw } \\
\text { shaw saw," and "shaw saw shaw" were } \\
\text { collected. Audio signals, image (US), and } \\
\text { video (lower face) were simultaneously } \\
\text { recorded. The mid-sagittal view of the } \\
\text { language through EdgeTrak Program } \\
\text { for extracting the contour of the tongue } \\
\text { was assessed. Errors in speech } \\
\text { production were defined as: (a) intrusion, } \\
\text { (b) omission, and (c) substitution. }\end{array}$ & $\begin{array}{l}\text { The competition during encoding of the } \\
\text { utterance increases with the increase in } \\
\text { sharing gestural structure, i.e., the more } \\
\text { gestures participate in a complex frequency } \\
\text { ratio, the greater the likelihood of errors } \\
\text { occurring. Furthermore, the non-coda } \\
\text { condition showed an error rate smaller } \\
\text { than the coda condition whereas a gestural } \\
\text { intrusion bias emerged mainly for the coda } \\
\text { condition. Finally, the proportion of different } \\
\text { types of errors (substitutions, coproduction } \\
\text { errors) differs depending on the type of } \\
\text { stimulus. }\end{array}$ \\
\hline $\begin{array}{l}\text { Rastadmehr } \\
\text { et al., } \\
2008^{(14)}\end{array}$ & $\begin{array}{l}\text { To document the } \\
\text { impact of a lateral } \\
\text { resection of the } \\
\text { tongue on the speed } \\
\text { of movement of the } \\
\text { tongue in patients } \\
\text { before and after } \\
\text { a partial tongue } \\
\text { resection, using the } \\
\text { B-mode of an US } \\
\text { image capture. }\end{array}$ & $\begin{array}{l}\text { Ten patients with } \\
\text { tongue cancer. } \\
\text { The average } \\
\text { age was } 45 \\
\text { years. Six normal } \\
\text { individuals } \\
\text { comprised the } \\
\text { comparison } \\
\text { group, with a } \\
\text { mean age of } 38 \\
\text { years. All subjects } \\
\text { were speakers } \\
\text { of Canadian } \\
\text { English. }\end{array}$ & $\begin{array}{l}\text { Patients with glossectomy were observed } \\
\text { for a few days before surgery and } 2 \\
\text { months after the surgery.At that point, } \\
\text { the healing is relatively complete and } \\
\text { swelling has subsided. If patients needed } \\
\text { radiotherapy, the assessment was } \\
\text { conducted before this procedure. US of } \\
\text { tongue movements in mid-sagittal plane } \\
\text { was carried out and acoustic data were } \\
\text { recorded simultaneously. }\end{array}$ & $\begin{array}{l}\text { Regarding the reading time, there was } \\
\text { no difference between normal speakers } \\
\text { and patients before or after surgery. When } \\
\text { compared the speed of the tongue in } \\
\text { patients with tongue cancer before and } \\
\text { after glossectomy, significant interaction } \\
\text { was found between the factors time and } \\
\text { tongue segment reached. No significant } \\
\text { interactions between the factors time and } \\
\text { type of reconstruction were found. The } \\
\text { study showed that a side partial resection } \\
\text { and the reconstruction led to a significant } \\
\text { increase in the speed of movement. This } \\
\text { finding was interpreted as evidence of an } \\
\text { increase in articulatory effort, resulting from a } \\
\text { compensatory motor learning. }\end{array}$ \\
\hline
\end{tabular}


Chart 1. Continuation

\begin{tabular}{|c|c|c|c|c|}
\hline Author(s) & Objective(s) & Participant(s) & Important procedures & Results \\
\hline $\begin{array}{l}\text { Campbell } \\
\text { et al., } \\
2010^{(15)}\end{array}$ & $\begin{array}{l}\text { To characterize the } \\
\text { gestures related to } \\
\text { the segment } / r \text { of the } \\
\text { American English. }\end{array}$ & $\begin{array}{l}\text { Ten native } \\
\text { speakers of } \\
\text { Canadian } \\
\text { English, five men } \\
\text { and five women, } \\
\text { aged between } 22 \\
\text { and } 36 \text { years. }\end{array}$ & $\begin{array}{l}\text { For this experiment, the combination of } \\
\text { US image in B/M mode (for language } \\
\text { data) and the Optotrak tracking (for data } \\
\text { labial opposition) was used. The acoustic } \\
\text { signal was also recorded. The gestures } \\
\text { of /r/ were analyzed in the context of } \\
\text { /e/ and /a/.The stimulus were read into } \\
\text { the phrase - "__ said x each _ "The } \\
\text { care for stabilizing of the head and of the } \\
\text { transducer was considered. Pictures of } \\
\text { the US were collected in the mid-sagittal } \\
\text { plane (B mode). Time was recorded until } \\
\text { the completion of the gesture, as well as } \\
\text { gestural magnitude. }\end{array}$ & $\begin{array}{l}\text { One anteroposteriorization in the initial } \\
\text { syllable was sequentially observed, while } \\
\text { in the final syllable the root gestures of the } \\
\text { tongue and lips precede the gesture of the } \\
\text { tongue blade. In regard to the magnitude, } \\
\text { the two most anterior gestures (blade and } \\
\text { lips) exhibited relative decrease of this } \\
\text { parameter in the final position. A significant } \\
\text { interaction was observed between time } \\
\text { and the magnitude of the gesture. A } \\
\text { notable finding of this study refers to the } \\
\text { distinction of the three gestures involved } \\
\text { in the production of /r/, which cannot be } \\
\text { represented in terms of a simple binary } \\
\text { phonological categorization of gestures. }\end{array}$ \\
\hline $\begin{array}{l}\text { Bressmann } \\
\text { et al., } \\
2010^{(16)}\end{array}$ & $\begin{array}{l}\text { Quantitatively } \\
\text { describe aspects } \\
\text { of coronal tongue } \\
\text { movements in the } \\
\text { different anatomical } \\
\text { regions of the tongue. }\end{array}$ & $\begin{array}{l}\text { Four normal } \\
\text { speakers (two } \\
\text { women } 23 \text { and } \\
24 \text { years old, and } \\
\text { two men } 25 \text { and } \\
34 \text { years old) and } \\
\text { one with partial } \\
\text { glossectomy. }\end{array}$ & $\begin{array}{l}\text { The US was recorded in four coronal } \\
\text { planes, being necessary to produce four } \\
\text { times the speech stimulus. Participants } \\
\text { should recite the last stanza of the poem } \\
\text { "I wandered lonely as a cloud". The lines } \\
\text { of the tongue's surface were extracted } \\
\text { through the Ultra-CATS software; then } \\
\text { the distance was measured between } \\
\text { US transducer and the surface of } \\
\text { the tongue. Then for the quantitative } \\
\text { description of the function of tongue } \\
\text { indicators total distance traveled and } \\
\text { concavity were calculated. }\end{array}$ & $\begin{array}{l}\text { The study found that there is greater } \\
\text { movement in the center of the tongue than } \\
\text { that in the lateral free margins. Depending } \\
\text { on the speaker, the greater distances } \\
\text { covered were focused in the anterior } \\
\text { or posterior region of the tongue. In all } \\
\text { speakers, the rear portion of the tongue } \\
\text { showed consistent grooving during the } \\
\text { connected speech. A more flat or convex } \\
\text { condition of the tongue was observed for } \\
\text { the anterior region. }\end{array}$ \\
\hline $\begin{array}{l}\text { Zharkova, } \\
2013^{(22)}\end{array}$ & $\begin{array}{l}\text { To describe the } \\
\text { image of US of the } \\
\text { tongue as a tool for } \\
\text { quantitative analysis } \\
\text { of the role of the } \\
\text { tongue in speakers } \\
\text { with cleft palate. }\end{array}$ & - & Descriptive study. & $\begin{array}{l}\text { Measures based on a single curve tongue } \\
\text { described in this study are: the excursion } \\
\text { index of the back and restriction position } \\
\text { index of the dorsum of the tongue; } \\
\text { both aim to directly assess the degree } \\
\text { of involvement of the tongue in the } \\
\text { articulation. Require stabilization of the } \\
\text { head. Measures based on a set of curves } \\
\text { of the tongue were also cited: tongue } \\
\text { dynamics, variability, and separation the } \\
\text { curves of the tongue. All measurements } \\
\text { can be used to compare the function of } \\
\text { tongue in speakers with cleft palate. }\end{array}$ \\
\hline
\end{tabular}


Chart 1. Continuation

\begin{tabular}{|c|c|c|c|c|}
\hline Author(s) & Objective(s) & Participant(s) & Important procedures & Results \\
\hline $\begin{array}{l}\text { Bacsfalvi } \\
\text { and } \\
\text { Bernhardt, } \\
2011^{(30)}\end{array}$ & $\begin{array}{l}\text { To investigate speech } \\
\text { production of seven } \\
\text { adolescents and } \\
\text { young adults with } \\
\text { hearing impairment } \\
\text { after 2-4 years } \\
\text { of intervention } \\
\text { through the US and } \\
\text { electropalatography. }\end{array}$ & $\begin{array}{l}\text { Seven speakers } \\
\text { (four men and } \\
\text { three women) with } \\
\text { severe to profound } \\
\text { hearing loss. }\end{array}$ & $\begin{array}{l}\text { Three sets of data were collected for } \\
\text { each patient: 1) pretreatment with visual } \\
\text { feedback, 2) immediately after using } \\
\text { the US, and 3) follow-up data. Real } \\
\text { or meaningless words were collected } \\
\text { separately or inserted in the sentence: } \\
\text { "I'm an __.". }\end{array}$ & $\begin{array}{l}\text { The trials for phases } 2 \text { and } 3 \text { of treatment } \\
\text { showed that five of the seven speakers } \\
\text { produced the segment with the same rate } \\
\text { of accuracy in both phases. Showed the } \\
\text { maintenance of levels of accuracy on a subject; } \\
\text { improvement in three subjects or a slight } \\
\text { regression for four subjects in the sample. } \\
\text { Some limitations of the study are identified } \\
\text { as: limited number of sample, short periods } \\
\text { of intervention, the use only of perceptual } \\
\text { analysis, and lack of access to a database of } \\
\text { normative data for comparison. }\end{array}$ \\
\hline $\begin{array}{l}\text { McMillan } \\
\text { and Corley, } \\
2010^{(31)}\end{array}$ & $\begin{array}{l}\text { To show that } \\
\text { similarities of } \\
\text { adjacent phonemes } \\
\text { affect their articulation } \\
\text { in predictable ways. }\end{array}$ & $\begin{array}{l}\text { Ten adults, native } \\
\text { speakers of } \\
\text { English. }\end{array}$ & $\begin{array}{l}\text { The phonetic similarities of phonemes } \\
\text { at the beginning of tongue twisters } \\
\text { were manipulated. Data were timed and } \\
\text { compared with electropalatography. } \\
\text { Analysis of the average sagittal outline of } \\
\text { the tongue over time was done with the } \\
\text { help of US and the VOT. }\end{array}$ & $\begin{array}{l}\text { Subphonemic representations consist } \\
\text { of articulatory gestures. Phonemes are } \\
\text { "malformed," in the sense that the aspects of } \\
\text { the production of more than one phoneme } \\
\text { are observed simultaneously. The bias for } \\
\text { gestural intrusion (as opposed to deletion or } \\
\text { substitution) follows naturally from the fact that } \\
\text { there are "cascades" activated for production. }\end{array}$ \\
\hline $\begin{array}{l}\text { Bressmann } \\
\text { et al., } \\
2011^{(32)}\end{array}$ & $\begin{array}{l}\text { To investigate the } \\
\text { articulation of deaf } \\
\text { alveolar plosive }[\mathrm{k}] \\
\text { in five speakers } \\
\text { with compensatory } \\
\text { articulation related to } \\
\text { cleft palate. }\end{array}$ & $\begin{array}{l}\text { Five individuals } \\
\text { with different } \\
\text { types of palatal } \\
\text { fissures repaired, } \\
\text { all speakers of } \\
\text { Canadian English. }\end{array}$ & $\begin{array}{l}\text { The tongue movements were recorded } \\
\text { by ultrasonography in the mid-sagittal } \\
\text { plane. The acoustic signal was recorded } \\
\text { simultaneously. Participants spoke five } \\
\text { repeat [a'ka], [i'ki] and [u'ku] after the } \\
\text { examiner. The perceptual and visual } \\
\text { analyses were reviewed and discussed } \\
\text { by three judges. }\end{array}$ & $\begin{array}{l}\text { The analysis revealed a variety of } \\
\text { compensatory strategies: glottal plosive, } \\
\text { plosive pharyngeal, mid-palatal plosive, } \\
\text { glottal, and velar coproductions. One } \\
\text { subject produced a sound of palate click } \\
\text { along with a mid-palatal plosive. The image } \\
\text { of US also revealed covert articulatory } \\
\text { movements, which would not be identified } \\
\text { through an isolated perceptual analysis. }\end{array}$ \\
\hline
\end{tabular}

Caption: US = ultrasound VOT $=$ voice onset time

Chart 2. Study that considered the application of ultrasound in the phonetics

\begin{tabular}{|c|c|c|c|c|}
\hline Author(s) & Objective(s) & Participant(s) & Important procedures & Results \\
\hline $\begin{array}{l}\text { Kochetov et al., } \\
2013^{(21)}\end{array}$ & $\begin{array}{l}\text { To use US to obtain the } \\
\text { images of tongue in various } \\
\text { Nepali lingual consonants. }\end{array}$ & $\begin{array}{l}\text { One native } \\
\text { speaker of } \\
\text { the dialect } \\
\text { Brahmin } \\
\text { participant. }\end{array}$ & $\begin{array}{l}\text { Analysis of syllabic sequences via } \\
\text { ultrasound images. Nepali coronal } \\
\text { consonants were observed. }\end{array}$ & $\begin{array}{l}\text { The results confirmed and extended } \\
\text { some observations on the Nepalese } \\
\text { coronal consonants, such as a single } \\
\text { contrasting place between dental, } \\
\text { alveolar, and retroflex. }\end{array}$ \\
\hline
\end{tabular}

Caption: US = ultrasound

The ultrasound technique allowed the measurement of the thickness of the masseter muscle as well as the diagnosis, the treatment plan, and the interdisciplinary prognosis — orthodontic, orthognathic, and Speech Language Pathology and Audiology. The technique proved to be efficient for measurements, and enabled the monitoring and setting discharge criteria for patients ${ }^{(8)}$.

It is believed that there are studies from other areas (e.g., dental) that are also used to search the masticatory muscles using ultrasound images, which could also be of particular interest to the Speech Language Pathology and Audiology. However, these were not included in this article, because they have not been located through the search strategies considered here.

\section{Ultrasound and swallowing}

From the search of the descriptors ultrasound versus swallowing, papers that are presented in Chart 5, the investigation of the displacement of the hyoid bone during the act of swallowing was frequent ${ }^{(19,23-26)}$. In addition to this, three other papers further investigated the thickness of the lingual musculature $^{(20,27)}$ and the pressure exerted by the tongue on the palate ${ }^{(19)}$.

The other objectives of the studies were concerned with the comparison of ultrasound and techniques already established for the investigation of swallowing, such as videofluoroscopy and endoscopy ${ }^{(23,27,38)}$, and also with the differentiation pattern 
Chart 3. Studies that have addressed the application of ultrasound in the voice

\begin{tabular}{|c|c|c|c|c|}
\hline Author(s) & Objective(s) & Participant(s) & Important procedures & Results \\
\hline $\begin{array}{l}\text { Krausert } \\
\text { et al., } \\
2011^{(33)}\end{array}$ & $\begin{array}{l}\text { To discuss the advantages, } \\
\text { disadvantages, and } \\
\text { clinical applicability of the } \\
\text { different measurement } \\
\text { techniques of the mucosal } \\
\text { wave (electroglottography } \\
\text { photoglottography and US) } \\
\text { and visualization techniques, } \\
\text { which include videokymography } \\
\text { (stroboscopic and digital high- } \\
\text { speed imaging). }\end{array}$ & - & $\begin{array}{l}\text { The various techniques and } \\
\text { their specific uses are reviewed } \\
\text { with the intention to help } \\
\text { researchers and clinicians to } \\
\text { choose a method for a given } \\
\text { situation and understand their } \\
\text { limitations and their potential } \\
\text { applications. }\end{array}$ & $\begin{array}{l}\text { The assessments of existing } \\
\text { research and recommendations } \\
\text { for future research are given to } \\
\text { foster both the quantitative study of } \\
\text { mucosal wave via a standardized } \\
\text { and accurate measurement of the } \\
\text { parameters of the same as for the } \\
\text { development of reliable methods } \\
\text { with which vocal disorders could be } \\
\text { diagnosed. }\end{array}$ \\
\hline $\begin{array}{l}\text { Cho et al., } \\
2012^{(34)}\end{array}$ & $\begin{array}{l}\text { To access the change in length } \\
\text { of the vocal fold with US. }\end{array}$ & $\begin{array}{l}35 \text { professional } \\
\text { singers. }\end{array}$ & $\begin{array}{l}\text { The individuals performed } \\
\text { ultrasonography during } \\
\text { respiration, phonation, and } \\
\text { singing. The length of the vocal } \\
\text { fold was measured in each } \\
\text { situation. }\end{array}$ & $\begin{array}{l}\text { Differences were found in each } \\
\text { phase. The authors concluded } \\
\text { that US can be used to check } \\
\text { the variation of the length of } \\
\text { the vocal folds. }\end{array}$ \\
\hline $\begin{array}{l}\text { Tićac et al., } \\
2012^{(35)}\end{array}$ & $\begin{array}{l}\text { To compare the values of } \\
\text { videofluoroscopy and US to } \\
\text { assess the tone of muscles } \\
\text { of the glottis and accurately } \\
\text { determine the hypertonic } \\
\text { laryngeal segment. }\end{array}$ & $\begin{array}{l}20 \text { patients with } \\
\text { inadequate } \\
\text { tracheoesophageal } \\
\text { voice that went to total } \\
\text { laryngectomy and } \\
\text { tracheoesophageal } \\
\text { prosthesis installation. }\end{array}$ & $\begin{array}{l}\text { After determining the } \\
\text { hypertonic laryngeal segment, } \\
\text { intramuscular lidocaine } \\
\text { was administered. Knowing } \\
\text { that videofluoroscopy is the } \\
\text { standard test for comparison } \\
\text { with US examination test, } \\
\text { contrast was administered } \\
\text { and dilatation of the segment } \\
\text { during swallowing, phonation, } \\
\text { and vocal rest was observed to } \\
\text { determine differences of tone } \\
\text { or disorder in-between before } \\
\text { and after administration of } \\
\text { lidocaine. }\end{array}$ & $\begin{array}{l}\text { The combination of the two } \\
\text { methods may provide better } \\
\text { results on the voice improvements. } \\
\text { Videofluoroscopy is an initial choice } \\
\text { examination to determine the } \\
\text { hypertonic segment and the } \\
\text { US is the method used to } \\
\text { facilitate the administration of } \\
\text { the drug more precisely. }\end{array}$ \\
\hline $\begin{array}{l}\text { Setlur and } \\
\text { Hartnick, } \\
2012^{(37)}\end{array}$ & $\begin{array}{l}\text { Review of studies on treatment } \\
\text { of unilateral vocal fold paralysis } \\
\text { in children. }\end{array}$ & - & Literature review. & $\begin{array}{l}\text { The authors reported that the } \\
\text { diagnosis and treatment plan are } \\
\text { made by laryngoscopy, US, and } \\
\text { electromyography. Today, there are } \\
\text { several studies suggesting specific } \\
\text { treatment for children, which can } \\
\text { lead to major impact on quality of } \\
\text { life of the same. }\end{array}$ \\
\hline
\end{tabular}

Caption: US = ultrasound 
Chart 4. Study that considered the application of ultrasound in the evaluation of a masticatory muscle

\begin{tabular}{|c|c|c|c|c|}
\hline Author(s) & Objective(s) & Parti & Important procedures & Results \\
\hline $\begin{array}{l}\text { Trawitzki et al., } \\
2011^{(8)}\end{array}$ & $\begin{array}{l}\text { To analyze the effect of } \\
\text { integrated treatment: } \\
\text { orthodontic, orthognathic } \\
\text { surgery, and myofunctional } \\
\text { therapy in the thickness/ } \\
\text { density of the masseter in } \\
\text { patients with Class III, } 3 \text { years } \\
\text { after orthognathic surgery. }\end{array}$ & $\begin{array}{l}\text { Longitudinal study with } \\
13 \text { patients with Class } \\
\text { III and } 15 \text { individuals } \\
\text { of the control group. }\end{array}$ & $\begin{array}{l}\text { Ultrasonography } \\
\text { of masseter was } \\
\text { performed during rest } \\
\text { and chewing/biting in } \\
\text { the three groups. }\end{array}$ & $\begin{array}{l}\text { Larger thickness of masseter values were } \\
\text { found in the postoperative group. Between } \\
\text { this group and the control group, there was } \\
\text { no difference on the right side of the muscle, } \\
\text { in situations of bite, and in the left side, in } \\
\text { situations of rest. The proposed treatment } \\
\text { resulted in improved thickness/density of the } \\
\text { masseter muscle in patients with Class III. }\end{array}$ \\
\hline
\end{tabular}

Chart 5. Studies that have addressed the application of ultrasonography in swallowing

\begin{tabular}{|c|c|c|c|c|}
\hline Author(s) & Objective(s) & Participant(s) & Important procedures & Results \\
\hline $\begin{array}{l}\text { Galén and Jost- } \\
\text { Brinkmann, 2010(17) }\end{array}$ & $\begin{array}{l}\text { To investigate the possibility } \\
\text { of using US to differentiate } \\
\text { patterns of visceral and } \\
\text { somatic swallowing. }\end{array}$ & $\begin{array}{l}11 \text { adults } \\
\text { with visceral } \\
\text { swallowing } \\
\text { pattern and } \\
13 \text { adults with } \\
\text { standard somatic } \\
\text { swallowing. }\end{array}$ & $\begin{array}{l}\text { Assessment and comparison } \\
\text { of sequences of } \mathrm{B} \text { and } \mathrm{M} \text { mode } \\
\text { during swallowing. } \\
\text { The extent and the speed of } \\
\text { vertical movement of the tongue } \\
\text { were determined, as well as the } \\
\text { total duration of swallowing. }\end{array}$ & $\begin{array}{l}\text { The parameters revealed large } \\
\text { intra- and interindividual variability. } \\
\text { There were no qualitative } \\
\text { differences in B-mode images. } \\
\text { The parameters measured in } \\
\text { M-mode images were not suitable } \\
\text { for differentiating between } \\
\text { patterns of visceral and somatic } \\
\text { swallowing. }\end{array}$ \\
\hline Steele et al., $2012^{(19)}$ & $\begin{array}{l}\text { To investigate the correlation } \\
\text { between non-invasive } \\
\text { measurements of timing the } \\
\text { pressure of the tongue on the } \\
\text { palate and the measure of } \\
\text { excursion of the hyoid bone. }\end{array}$ & $\begin{array}{l}20 \text { healthy adults } \\
\text { (10 men and } 10 \\
\text { women), between } \\
20 \text { and } 39 \text { years. }\end{array}$ & $\begin{array}{l}\text { The temporal relations between } \\
\text { the events of the pressure of } \\
\text { the tongue on the palate and } \\
\text { the hyoid movement during } \\
\text { swallowing were explored. }\end{array}$ & $\begin{array}{l}\text { The creation of pressure of } \\
\text { the tongue on the palate and } \\
\text { the movement of the hyoid are } \\
\text { distinct phenomena that follow the } \\
\text { swallowing. }\end{array}$ \\
\hline $\begin{array}{l}\text { Tamura et al., } \\
2012^{(20)}\end{array}$ & $\begin{array}{l}\text { To assess sarcopenia of } \\
\text { tongue muscles by measuring } \\
\text { the thickness of the tongue } \\
\text { with US, as well as to clarify } \\
\text { its relation with nutritional } \\
\text { status in the elderly. }\end{array}$ & $\begin{array}{l}104 \text { elderly } \\
\text { people ( } 32 \text { men } \\
\text { and } 72 \text { women, } \\
\text { average age of } \\
80.3 \text { years). }\end{array}$ & $\begin{array}{l}\text { The frontal and lateral position } \\
\text { of the tongue was considered } \\
\text { using US stable images. } \\
\text { The measurement was } \\
\text { performed twice and the } \\
\text { average value was obtained. }\end{array}$ & $\begin{array}{l}\text { The thickness of the tongue is } \\
\text { related to nutritional status in } \\
\text { the elderly. The dysfunction and } \\
\text { abnormality of the tongue can } \\
\text { also be a cause for dysphagia. } \\
\text { Malnutrition can lead to } \\
\text { sarcopenia (decreased muscle } \\
\text { mass and strength), not only } \\
\text { in skeletal muscles but also on } \\
\text { the tongue. }\end{array}$ \\
\hline $\begin{array}{l}\text { Huang et al., } \\
2009^{(23)}\end{array}$ & $\begin{array}{l}\text { To explore the reliability of the } \\
\text { US examination of the hyoid- } \\
\text { larynx approximation and its } \\
\text { application in stroke patients } \\
\text { with and without dysphagia. }\end{array}$ & $\begin{array}{l}55 \text { participants: } \\
15 \text { healthy } \\
\text { individuals and } \\
20 \text { individuals } \\
\text { who had CVA, } \\
\text { but did not show } \\
\text { changes in } \\
\text { swallowing, and } \\
20 \text { individuals } \\
\text { who had CVA and } \\
\text { dysphagia. }\end{array}$ & $\begin{array}{l}\text { The distance between the } \\
\text { thyroid cartilage and the hyoid } \\
\text { bone during swallowing was } \\
\text { measured by US. Ten patients } \\
\text { with stroke and dysphagia also } \\
\text { underwent videofluoroscopy. }\end{array}$ & $\begin{array}{l}\text { The percentage change in } \\
\text { hyoid-larynx approximation } \\
\text { was very similar between } \\
\text { the US examination and } \\
\text { videofluoroscopy, showing the } \\
\text { reliability of the US to that extent. } \\
\text { The hyoid-larynx approximation } \\
\text { was significantly reduced in } \\
\text { patients with CVA and dysphagia. }\end{array}$ \\
\hline $\begin{array}{l}\text { Scarborough et al., } \\
2010^{(24)}\end{array}$ & $\begin{array}{l}\text { To acquire normative } \\
\text { parameters about the } \\
\text { maximum displacement of } \\
\text { the hyoid obtained by US, in a } \\
\text { sample of healthy children. }\end{array}$ & $\begin{array}{l}29 \text { children of } \\
\text { preschool age. }\end{array}$ & $\begin{array}{l}\text { The maximum displacement } \\
\text { of the hyoid bone, determined } \\
\text { from a sequence of frames } \\
\text { during analysis in spontaneous } \\
\text { swallowing, was observed. }\end{array}$ & $\begin{array}{l}99 \% \text { of children showed } \\
\text { displacement of the hyoid bone } \\
\text { within } 3 \mathrm{~cm} \text { as normal parameters, } \\
\text { and the US proved to be a reliable } \\
\text { method for such analysis. }\end{array}$ \\
\hline
\end{tabular}


Chart 5. Continuation

\begin{tabular}{|c|c|c|c|c|}
\hline Author(s) & Objective(s) & Participant(s) & Important procedures & Results \\
\hline $\begin{array}{l}\text { Macrae et al., } \\
2012^{(25)}\end{array}$ & $\begin{array}{l}\text { To quantify the movement of } \\
\text { the hyoid via US through an } \\
\text { analysis of inter- and intra- } \\
\text { evaluators reliability. }\end{array}$ & $\begin{array}{l}\text { Five individuals } \\
\text { (two men and } \\
\text { three women, } \\
\text { aged between } 20 \\
\text { and } 50 \text { years). }\end{array}$ & $\begin{array}{l}\text { The distance between the } \\
\text { mandible and the hyoid bone } \\
\text { and the change of displacement } \\
\text { of the hyoid bone from a } \\
\text { reference point were calculated. }\end{array}$ & $\begin{array}{l}\text { Measurements at rest and in } \\
\text { maximum displacement of } \\
\text { the hyoid bone, taken by each } \\
\text { evaluator, were highly correlated. } \\
\text { The US is an important tool for } \\
\text { evaluating the displacement of the } \\
\text { hyoid bone in dysphagia. }\end{array}$ \\
\hline $\begin{array}{l}\text { Yabunaka et al., } \\
2011^{(26)}\end{array}$ & $\begin{array}{l}\text { To use US to assess the } \\
\text { trajectories of movement of } \\
\text { the hyoid bone and age- } \\
\text { related changes during } \\
\text { swallowing in healthy subjects. }\end{array}$ & $\begin{array}{l}30 \text { adult } \\
\text { individuals, } \\
\text { equally divided } \\
\text { into three age } \\
\text { groups: } 20-39 \\
\text { years, } 40-59 \\
\text { years, and } 60-79 \\
\text { years. }\end{array}$ & $\begin{array}{l}\text { The US transducer was } \\
\text { positioned above the larynx; the } \\
\text { hyoid bone should be centered } \\
\text { on the screen. The individuals } \\
\text { swallowed five times } 5 \text {-ml water. } \\
\text { The resting point of the hyoid } \\
\text { bone and other periods were } \\
\text { measured. }\end{array}$ & $\begin{array}{l}\text { The trajectory of the hyoid bone } \\
\text { was easily observed with the US. } \\
\text { It was presented in four stages: } \\
\text { 1) elevation after swallowing; } \\
\text { 2) anteriorization; } 3 \text { ) temporary } \\
\text { phase (position of maximum } \\
\text { elevation); and 4) return to the rest } \\
\text { position. The time of stages } 1,2 \text {, } \\
\text { and } 4 \text { increased significantly with } \\
\text { increasing age. The opposite was } \\
\text { observed for the third phase. }\end{array}$ \\
\hline Hsiao et al., $2012^{(27)}$ & $\begin{array}{l}\text { To measure changes in the } \\
\text { thickness of the tongue in } \\
\text { stroke patients with dysphagia } \\
\text { and the displacement of the } \\
\text { hyoid bone during swallowing. }\end{array}$ & $\begin{array}{l}60 \text { stroke patients } \\
\text { and } 30 \text { healthy } \\
\text { individuals for the } \\
\text { control group. }\end{array}$ & $\begin{array}{l}\text { The thickness of the tongue } \\
\text { and the displacement of the } \\
\text { hyoid bone were measured. } \\
\text { As assessment tools, } \\
\text { videofluoroscopy (on } 12 \\
\text { patients) and the US were used. }\end{array}$ & $\begin{array}{l}\text { The thickness of the tongue } \\
\text { and the hyoid displacement } \\
\text { was smaller in the group whose } \\
\text { diet occurred by probe. The US } \\
\text { proved as a reliable measure as } \\
\text { it showed good correlation with } \\
\text { videofluoroscopy. }\end{array}$ \\
\hline $\begin{array}{l}\text { Komori et al., } \\
2008^{(38)}\end{array}$ & $\begin{array}{l}\text { To compare the technique that } \\
\text { combines endoscopy and US } \\
\text { with fluoroscopy. }\end{array}$ & $\begin{array}{l}\text { Eight healthy } \\
\text { men, aged } \\
\text { between } 25 \text { and } \\
31 \text { years. }\end{array}$ & $\begin{array}{l}\text { The laryngeal elevation } \\
\text { corresponded to the maximum } \\
\text { height, verified by fluoroscopy } \\
\text { and US. }\end{array}$ & $\begin{array}{l}\text { The moment of the elevation was } \\
\text { similar among the investigated } \\
\text { techniques. Distances and } \\
\text { durations of maximum laryngeal } \\
\text { elevation correlated significantly. } \\
\text { The technique of fluoroscopy and } \\
\text { US may show the swallowing } \\
\text { function as efficiently as } \\
\text { videofluoroscopy. }\end{array}$ \\
\hline $\begin{array}{l}\text { Yabunaka et al., } \\
2012^{(39)}\end{array}$ & $\begin{array}{l}\text { To investigate the application } \\
\text { of US to quantify the patterns } \\
\text { of geniohyoid muscles during } \\
\text { swallowing and to evaluate } \\
\text { these patterns according to age } \\
\text { and gender. }\end{array}$ & $\begin{array}{l}60 \text { adults ( } 30 \text { men } \\
\text { and } 30 \text { women), } \\
\text { divided into } \\
\text { three age groups } \\
\text { (20-39 years, } \\
40-59 \text { years, and } \\
60-79 \text { years). }\end{array}$ & $\begin{array}{l}10 \mathrm{~mL} \text { water was administered in } \\
\text { five repetitions Every geniohyoid } \\
\text { muscle movement was recorded } \\
\text { in real time. Simultaneous images } \\
\text { of swallowing were captured } \\
\text { in two regions along the lateral } \\
\text { geniohyoid muscle wall. }\end{array}$ & $\begin{array}{l}\text { The moving average distance and } \\
\text { the duration of the movement of the } \\
\text { mylohyoid muscle-geni increase } \\
\text { gradually with age. No difference } \\
\text { was found in measurements during } \\
\text { swallowing between the sexes, in } \\
\text { all age groups. }\end{array}$ \\
\hline
\end{tabular}

Caption: US = ultrasound; CVA = cerebral vascular accident

of somatic and visceral swallowing ${ }^{(17)}$ and, finally, with research movement patterns of geniohyoid muscles ${ }^{(39)}$.

As for the sample evaluated in the mentioned papers $^{(17,19,20,23-27,38,39)}$, the groups comprised individuals with typical swallowing (from children to the elderly) and with altered swallowing, due to some underlying diseases, such as cerebral vascular accident (CVA). The number of participants varied considerably from 5 to 104 among the articles, with an average of 42.5 participants.
The research ${ }^{(19,23-26)}$ highlighted the ultrasound as an important tool for evaluating the displacement of the hyoid bone in swallowing research. Reducing the movement of the hyoid bone has been associated with the increased risk for intrusion of waste in the larynx and the air passages. Comparing the ultrasound image with other assessment tools ${ }^{(23,27,38)}$, ultrasound image was considered as a reliable, relatively inexpensive, and noninvasive method of research, although it has received little attention in the literature. 
Through the use of ultrasound, some authors were able to verify that the pressure of the tongue on the palate and the hyoid movement are distinct phenomena as a result of swallowing ${ }^{(19)}$. However, correlation was observed between the thickness of the tongue, verified by ultrasound images, and the nutritional status of stroke patients with dysphagia. Thus, malnutrition can induce sarcopenia (decreased muscle mass and strength) and the dysfunction and abnormality of the tongue may also be an indicator of dysphagia ${ }^{(20)}$.

As ultrasound still is underused in studies of dysphagia, in most papers further research involving this technique in the standardization of reliable measures is suggested to assess swallowing. However, most studies already confirmed the ultrasound images as a possibility in assessing the dynamics of swallowing.

\section{CONCLUSION}

Studies that investigated the use of the ultrasound technique in the field of Speech Language Pathology and Audiology in the past 5 years were found. These studies confirmed the new possibilities of the use of ultrasound in all subareas of Speech Language Pathology and Audiology considered in the present literature review, striving for a more accurate diagnosis, more detailed assessments, differentiated therapeutic processes, and greater cost-effectiveness.

The majority ( 27 of 28 articles selected for this literature review) of the studies found were carried out in other countries, highlighting the field need to update itself and the necessity to practice the search through the use of new instruments in the researches and in Speech Language Pathology and Audiology Clinical Therapy in Brazil.

\section{ACKNOWLEDGMENT}

We thank the Fundação de Amparo à Pesquisa do Estado do Rio Grande do Sul (FAPERGS) and the Coordenação de Aperfeiçoamento de Pessoal de Nível Superior (CAPES) for providing two $\mathrm{PhD}$ scholarships, for the first and to the third author of this work, during this study.

* LSB, BCB, and RMM were jointly responsible for the delimitation of the study, literature search, and its writing; MKS, CLM, and HBM supervised the data collection, tabulation and analysis, and provided guidance during all stages of the study elaboration.

\section{REFERENCES}

1. Gregio FN, Camargo ZA. Dados de tempo de início do vozeamento (VOT) na avaliação do sinal vocal de indivíduos com paralisia unilateral de prega vocal. Disturb Comum. 2005;17(3):289-97.

2. Melo RM, Mota HB, Mezzomo CL, Brasil BC, Lovatto L, Arzeno L. Parâmetros acústicos do contraste de sonoridade das plosivas no desenvolvimento fonológico típico e no desviante. Rev Soc Bras Fonoaudiol. 2012;17(3):304-12.
3. Marino VCC, Berti LC, Lima-Gregio AM. Características acústicas da oclusiva glotal associada à sequência de Pierre Robin: estudo de caso. Rev CEFAC. 2013;15(2):466-77.

4. Giacchini V, Mota HB, Mezzomo CL. Variáveis relevantes no processo terapêutico para a aquisição do onset complexo na fala de crianças com desvio fonológico. Rev CEFAC (no prelo).

5. Berti LC. Investigação da produção de fala a partir da ultrassonografia do movimento de língua. In: $19^{\circ}$ Congresso Brasileiro de Fonoaudiologia; 2010; Curitiba. Revista da Sociedade Brasileira de Fonoaudiologia: suplemento. Curitiba: Sociedade Brasileira de Fonoaudiologia; 2010.

6. Pereira LCK, Gregio FN, Svicero MAF, Nan PC, Madureira S, Camargo ZA. Caracterização de vogais orais e nasais por dados de ultrassonografia, ressonância magnética e análise acústica. In: $19^{\circ}$ Congresso Brasileiro e $8^{\circ}$ Internacional de Fonoaudiologia; 2011; São Paulo. Revista da Sociedade Brasileira de Fonoaudiologia: suplemento. São Paulo: Sociedade Brasileira de Fonoaudiologia; 2011. p. 980.

7. Svicero MAF, Pereira LK, Nan PC, Isolan-Cury R, Camargo Z. Dados preliminares de análise de fala por meio da ultrassonografia. In: $19^{\circ}$ Congresso Brasileiro e $8^{\circ}$ Internacional de Fonoaudiologia; 2011; São Paulo. Revista da Sociedade Brasileira de Fonoaudiologia: suplemento. São Paulo: Sociedade Brasileira de Fonoaudiologia; 2011. p. 728.

8. Trawitzki LV, Dantas RO, Elias-Júnior J, Mello-Filho FV. Masseter muscle thickness three years after surgical correction of class III dentofacial deformity. Arch Oral Biol. 2011;56(8):799-803.

9. Berti LC. Investigação ultrassonográfica dos erros de fala infantil à luz da Fonologia Gestual. In: Ferreira-Gonçalves G, Brum-de-Paula M. Dinâmica dos movimentos articulatórios: sons, gestos e imagens. Pelotas (RS): Editora da UFPel; 2013. p.127-44.

10. Francisco DT, Pagan-Neves LO, Wertzner HF. Aplicação da ultrassonografia de fala como ferramenta auxiliar ao diagnóstico do transtorno fonológico. In: $4^{\circ}$ Seminário de Aquisição fonológica; 2013; Santa Maria. $4^{\circ}$ Seminário de Aquisição fonológica: resumos e programação. Pelotas (RS): Editora da UFPel; 2013. p. 33-4.

11. Bernhardt BM, Bacsfalvi P, Adler-Bock M, Shimizu R, Cheney A, Giesbrecht N, et al. Ultrasound as visual feedback in speech habilitation: exploring consultative use in rural British Columbia, Canada. Clin Linguist Phon. 2008;22(2):149-62.

12. Modha G, Bernhardt BM, Church R, Bacsfalvi P. Case study using ultrasound to treat /r/. Int J Lang Commun Disord. 2008;43(3):323-9.

13. Pouplier $\mathrm{M}$. The role of a coda consonant as error trigger in repetition tasks. J Phon. 2008;36(1):114-40.

14. Rastadmehr O, Bressmann T, Smyth R, Irish JC. Increased midsagittal tongue velocity as indication of articulatory compensation in patients with lateral partial glossectomies. Head Neck. 2008;30(6):718-26.

15. Campbell F, Gick B, Wilson I, Vatikiotis-Bateson E. Spatial and temporal properties of gestures in North American English /r/. Lang Speech. 2010;53(1):49-69.

16. Bressmann T, Flowers H, Wong W, Irish JC. Coronal view ultrasound imaging of movement in different segments of the tongue during paced recital: findings from four normal speakers and a speaker with partial glossectomy. Clin Linguist Phon. 2010;24(8):589-601.

17. Galén S, Jost-Brinkmann PG. B-mode and M-mode ultrasonography of tongue movements during swallowing. J Orofac Orthop. 2010;71(2):125-35.

18. Zharkova N, Hewlett N, Hardcastle WJ. Coarticulation as an indicator of speech motor control development in children: an ultrasound study. Motor Control. 2011;15(1):118-40.

19. Steele C, Sasse C, Bressmann T. Tongue-pressure and hyoid movement timing in healthy liquid swallowing. Int J Lang Commun Disord. 2012;47(1):77-83.

20. Tamura F, Kikutani T, Tohara T, Yoshida M, Yaegaki K. Tongue thickness relates to nutritional status in the elderly. Dysphagia. 2012;27(4):556-61.

21. Kochetov A, Pouplier M, Truong S. A preliminary ultrasound study of Nepali lingual articulations. J Acoust Soc Am. 2013;13:1-9.

22. Zharkova N. Using ultrasound to quantify tongue shape and movement characteristics. Cleft Palate Craniofac J. 2013;50(1):76-81. 
23. Huang YL, Hsieh SF, Chang YC, Chen HC, Wang TG. Ultrasonographic evaluation of hyoid-larynx approximation in dysphagic stroke patients. Ultrasound Med Biol. 2009;35(7):1103-8.

24. Scarborough DR, Waizenhofer S, Siekemeyer L, Hughes M. Sonographically measured hyoid bone displacement during swallow in preschool children: a preliminary study. J Clin Ultrasound. 2010;38(8):430-4.

25. Macrae PR, Doeltgen SH, Jones RD, Huckabee ML. Intra- and inter-rater reliability for analysis of hyoid displacement measured with sonography. J Clin Ultrasound. 2012;40(2):74-8.

26. Yabunaka K, Sanada H, Sanada S, Konishi H, Hashimoto T, Yatake H, et al. Sonographic assessment of hyoid bone movement during swallowing: a study of normal adults with advancing age. Radiol Phys Technol. 2011;4(1):73-7.

27. Hsiao MY, Chang YC, Chen WS, Chang HY, Wang TG. Application of ultrasonography in assessing oropharyngeal dysphagia in stroke patients. Ultrasound Med Biol. 2012;38(9):1522-8.

28. Gick B. The use of ultrasound for linguistic phonetic fieldwork. J Int Phon Assoc. 2002;32(2):113-21.

29. Bressmann T. Quantitative assessment of tongue shape and movement using ultrasound imaging. In: $3^{\text {rd }}$ Conference on Laboratory Approaches to Spanish Phonology; 2008. Somerville (MA); 2008. p. 101-6.

30. Bacsfalvi P, Bernhardt BM. Long-term outcomes of speech therapy for seven adolescents with visual feedback technologies: ultrasound and electropalatography. Clin Linguist Phon. 2011;25(11-12):1034-43.
31. McMillan CT, Corley M. Cascading influences on the production of speech: evidence from articulation. Cognition. 2010;117(3):243-60.

32. Bressmann T, Radovanovic B, Kulkarni GV, Klaiman P, Fisher D. An ultrasonographic investigation of cleft-type compensatory articulations of voiceless velar stops. Clin Linguist Phon. 2011;25(11-12):1028-33.

33. Krausert CR, Olszewski AE, Taylor LN, McMurray JS, Dailey SH, Jiang JJ. Mucosal wave measurement and visualization techniques. J Voice. 2011;25(4):395-405.

34. Cho W, Hong J, Park H. Real-time ultrasonographic assessment of true vocal fold length in professional singers. J Voice. 2012;26(6):819.e1-6.

35. Tićac R, Candrlić B, Juranić J, Pavelić G, Pedisić D, Pusić M, et al. The role of videofluoroscopy and ultrasound in assessing pharyngoesophageal muscle tone after laryngectomy. Coll Antropol. 2012;36(Suppl 2):125-8.

36. Pedisić D, Tićac R, Candrlić B, Marijić B, Sepić T, Malvić G, et al. The use of ultrasound in determining the length of the Provox II voice prosthesis. Coll Antropol. 2012;36(Suppl 2):103-6.

37. Setlur J, Hartnick CJ. Management of unilateral true vocal cord paralysis in children. Curr Opin Otolaryngol Head Neck Surg. 2012;20(6):497-501.

38. Komori M, Hyodo M, Gyo K. A swallowing evaluation with simultaneous videoendoscopy, ultrasonography and videofluorography in healthy controls. J Otorhinolaryngol Relat Spec. 2008;70(6):393-8.

39. Yabunaka K, Konishi H, Nakagami G, Sanada H, Iizaka S, Sanada S, et al. Ultrasonographic evaluation of geniohyoid muscle movement during swallowing: a study on healthy adults of various ages. Radiol Phys Technol. 2012;5(1):34-9. 